\title{
Somatic Embryogenesis; A Highly Promising Technique for Conservation of Tecomella Undulata - A Multi-Purpose Tree on the Verge of Extinction
}

Sasan Rastgoo ( $\nabla$ snrastgoo@yahoo.com )

Persian Gulf University https://orcid.org/0000-0001-7354-6168

\section{Research Article}

Keywords: Plant Cell, Tissue and Organ Culture (PCTOC) PCTO-D-21-00344

Posted Date: August 26th, 2021

DOl: https://doi.org/10.21203/rs.3.rs-769743/v1

License: (c) (1) This work is licensed under a Creative Commons Attribution 4.0 International License.

Read Full License 


\section{Abstract}

Over-exploitation of trees by increasing human population has put an enormous pressure especially on those species having slow growth and low reproduction rate. Desert teak (Tecomella undulata (Sm.) Seem) a multipurpose agroforestry tree of arid zone has fallen on the verge of extinction in Iran due to lack of efficient seed reproduction. Inherent low adventitious rooting has caused vegetative mass macroand micropropagation (organogenesis pathway) of this tree to be unsuccessful. Somatic embryogenesis (SE) pathway by production of bipolar embryo capable of development into a complete plantlet can solve the problem. Hence, a research was carried out to evaluate the feasibility of in vitro regeneration of the tree by SE. Ovary extracted from un-pollinated flower was cultured in the media supplemented with different auxins and cytokinins (CKs). The results showed a-naphthalene acetic acid (NAA) was superior in induction of embryogenic callus (EC). NAA ranging 5.4-21.5 $\mu \mathrm{M}$ could induce the highest ECs which exhibited developing pro-embryogenic masses (PEMs) and globular somatic embryos. Both CKs, thidiazuron (TDZ) and $\mathrm{N}^{6}$-benzyladenine (BA), though induced good callogenesis at low concentrations but the formed calli were non-embryogenic. Proliferation of NAA-induced ECs revealed that hormone-free medium is the best choice. However, the media containing 40.5 and $54 \mu \mathrm{M}$ NAA alone could also induce somatic embryos along with callus proliferation. Effort for maturation of the obtained globular, hearshaped and torpedo embryos did not yield satisfactory results. Low BA-contained medium led to secondary SE. More research is expected to be undertaken to optimize SE in desert teak.

\section{Introduction}

The rapid increase in human population size, global climate change, and demand for timber and various plant by-products has put massive pressure on many tree species. In the meantime, those slow growing woody species having low reproduction rate, due to inherent or environmental causes, are more vulnerable to extinction threat. In order to avoid or reduce such threat, developing new technologies for tree propagation, improvement, and breeding seems to be the best, even the sole strategy. The science of biotechnology has been involving to preserve and genetically improve numerous plant species including endangered species.

Tecomella undulata (Sm.) Seem called as Desert teak, Marwar teak, or Rohida a woody perennial species from family Bignoniaceae, considered as an agro-forestry tree is a multipurpose tree which is well adopted in arid and semi-arid zones of a region extended from the Arabian Peninsula to southern Iran, southern Pakistan and northwestern part of India (Goodin and Northington 1985). The tree is a drought, fire, frost and wind resistant, biomass producer tolerating drained loamy to sandy loam soils having $\mathrm{pH}$ in the range of 6.5-8.0 and a highly precious and nearly evergreen small ornamental tree under hot arid and semi-arid climates. It is greatly valuable for its capabilities to stabilize sandy soils in desert areas and provide forage, fuel and high quality timber beside various industrial by-products to support the life system of arid and semi-arid ecosystems (Roshan et al., 2011; Kalia et al., 2014). Leaf, bark, wood and roots of desert teak have high pharmaceutical properties (Joshi et al., 1977; Ahmad et al., 1994; Chal et al., 2011). 
This attractive, beautiful flowering tree suitable for creating green landscape in dry areas, forestry, and desert greening, potentially can be a key environmental, ecofriendly element to boom ecotourism in desert areas. In Iran, the tree has distribution as fairly small, pure forest masses in tropical and sub-tropical regions of Bushehr, Khuzestan, Hormozgan, Fars, Kerman, and Sistan and Baluchistan provinces. But the tree is now heading towards extinction due to several reasons. Although long term severe drought periods, over-exploitation for timber and other plant parts, and also destruction of its small populations during urban, agricultural, and industrial expansion during past three decades have had devastating impacts on its habitats, but the first and foremost reason for its populations decline is unavailability of an efficient propagation tool to retrieve the existing small masses. The biggest bottleneck is the tree's nearly absolute failure in seed production across its almost all habitats in the country (the author's observations). Being hard-to-root in cutting propagation (Rastgoo, 2014; Tyagi et al., 2011) has aggravated the problem and created a deadlock in propagation of this species. This species has also been designated as "threatened" and "endangered" in India (Kalia et al., 2014; Meena et al., 2019). Hussain et al. (2010) announced that T. undulata has become extinct in Karachi, Pakistan. Moreover, United Nations Environment Programme World Conservation Monitoring Centre (UNEP-WCMC) Nairobi, Kenya, has included T. undulata into "Category 1-Indeterminate" of their list of threatened plants to emphasize the urgent need for conservation of the species (Kalia et al., 2014).

Biotechnology-based techniques provide efficient methods of micropropagation, genetic improvement, and for germplasm conservation of tropical and subtropical trees (Litz et al., 1997). Among these, Micropropagation also known as in vitro propagation, potentially offering breakthrough in clonal mass production of recalcitrant species, has been attempted widely in forest trees and particularly in desert teak several times during past three decades. However, so far, nearly all the attempts have focused on utilizing organogenesis pathway using nodal or internodal segments taken from mature tree stands or in vitro propagules, and/or callus derived from them as explant (Raj Bhansali, 1993; Nandwani et al., 1996; Robinson et al., 2005; Aslam et al., 2009; Tyagi \& Tomar, 2013; Chhajer and Kalia, 2017). Despite valuable efforts, organogenic regeneration pathway has not yielded a satisfactory propagation protocol for this species since it has many limitations, the most important one is very low adventitious rooting ability of the explants resulting in poor regeneration efficiency.

Somatic Embryogenesis (SE) is an alternative pathway for mass cloning of elite, endangered, or high demanding genotypes as it has various advantages over organogenesis besides easy manipulation by using protoplast and molecular techniques for the improvement of various species. SE is the capacity of differentiated cells to acquire embryogenic competence (Robert et al., 2015). The feasibility of plantlet regeneration from single cell origin, faster multiplication rate, the possibility of automating the large-scale production of embryos in bioreactors and field planting as synthetic seeds, direct development of produced embryos into plantlet for their bipolar nature so bypassing the rooting stage needed in organogenic regeneration, are some of the precious advantages of SE (Guan et al., 2016, Ammirato 1983). Plant regeneration via SE passes four steps: (i) initiation of somatic embryos from the primary explant, (ii) proliferation of embryogenic cultures, (iii) maturation of somatic embryos, and (iv) 
regeneration of plants from somatic embryos (Santos et al., 2002). If the primary explant is callus tissue, the regeneration process is considered as indirect (callus-mediated) SE.

SE of agro-forestry trees has been achieved in number of dicotyledonous and monocotyledonous angiosperms. However, adventive embryogenesis has been reported for relatively fewer arid zone woody species appear to be recalcitrant to in vitro culture and regeneration of plants (Raj Bhansali and Singh, 2000). In woody plants, pioneering research on SE was only observed to form the embryo-like structures in sandalwood (Santalum album L.) and several conifers. However, these embryo-like tissues did not grow into complete plants (Guan et al., 2016). Since then, numerous researches have been conducted in the context of SE in woody species, some recent ones are on Eucalyptus species (Corredoira et al., 2015), The East Indian sandalwood tree (S. album L.) (Peeris and Senarath, 2015), black alders (Alnus glutinosa) (Corredoira et al., 2013), Terminalia chebula Retz. (Anjaneyulu and Giri, 2018) and Picea species (Hazubska-Przybył et al., 2020). Based on a thorough literature review prior to commencement of the present study, no research work was found undertaken for micropropgation of $T$. undulata via SE. Thus, initiating a research in this context was seen critically necessary.

On the other side, most research works on SE have utilized plant materials collected from mature vegetative growth. Keeping in the view that SE mimics the events occurring during in vivo zygotic embryogenesis (Zimmerman, 1993) and that in cases of woody species the juvenility of explant, beside the culture conditions, is one of the two major embryogenesis induction determinants (Isah, 2016), it can be logically inferred the explants extracted from plant reproductive organs can be more competent to induce SE under optimized in vitro culture conditions. Higher SE competence of grapes immature flowers than the explants taken from vegetative tissues has previously been cited by Gambino et al. (2007). Hence, I decided to use ovary of un-pollinated flowers of desert teak as the explant.

According to the author's previous study (Rastgoo, 2016), Desert teak stamens were unresponsive to the culture media supplemented with different combinations of various plant growth regulators (PGRs) while among pistil components (ovary, style and stigma) ovary was found as best responsive explant.

Previously, better formation of embryogenic callus (EC) and SE from ovary explant has laso been reported in three Vitis species (Martinelli et al. 2003; Gambino et al. 2007; Gambino et al. 2021). Therefore, it was planned to investigate regeneration capability of immature, un-pollinated ovaries of desert teak under in vitro conditions more extensively. Earlier, frequent reports on usage of ovary explant for in vitro regeneration of several other species including herbaceous such as Crocus sativus (Bhagyalakshmi 1999), Phlox paniculata (Fraga et al. 2004), and Narcissus L. (Malik, 2008), and woody like Azadirachta indica (Srivastava et al., 2009) and Salix (Agrawal and Gebhardt, 1994 ) have been published. SE changes somatic cells to embryonic cells in a physiological sequence that is tightly regulated by a delicate balance of PGRs (Dinani et al. 2018). Such a balance is obviously associated with endogenous PGRs of explant. Thus, in addition to use inherently the most potent explant type for SE, finding the most effective PGRs at optimum concentrations to be used as the culture medium supplements is the second important priority in this filed. 
Hence, the present study was performed with aims of evaluating morphogenic response of ovary of Tecomella undulata to different PGRs, discovering embryogenic capacity of the induced calli, and optimizing a protocol for induction of SE in this species. Influence of changing sucrose concentration in the culture medium on developmental maturity of the induced embryonic structures was also examined.

\section{Materials And Methods}

\subsection{Culture media preparation}

In this study, the basal media that were used consisted of MS medium modification No.1 (containing half strength of MS macroelements, full strength of microelements and vitamins) and MS modification No.2 (with full strength of MS macroelements and microelements and Gamborg's B5 vitamins) supplemented

with $30 \mathrm{~g} \mathrm{I}^{-1}$ sucrose, unless otherwise mentioned. Agar was applied to the media at the rate of $0.8 \%$. The media and agar were procured from HiMedia Company, India. The PGRs used in the study were 2,4-D, NAA, IBA, IAA, GA,$B A$, and TDZ which were added to media at concerned concentrations before $\mathrm{pH}$ adjustment. The medium $\mathrm{pH}$ was adjusted to 5.8 before addition of agar and autoclaving at $121^{\circ} \mathrm{C}$ and $1.1 \mathrm{~atm}$ pressure for $20 \mathrm{~min}$.

\subsection{Explants preparation and culture}

This research was carried out in four experiments. For the first two experiments, inflorescences having unopened, unpollinated blooms at balloon stage were harvested from mature tree stands growing in Shabankareh habitat, Bushehr province in southwestern border of Iran, at beginning of March till first half of April in 2019 and transferred to the plant tissue culture laboratory of Department of Horticultural Science at Persian Gulf University, Borazjan, Iran. Individual unopened blooms were separated from the inflorescence, surface sterilized through immersing into $96 \%$ ethanol for $15 \mathrm{sec}$. Then, after removal of calyx, petals and stamens by a sterilized forcep inside a functioning laminar air flow cabinet, pistils were dissected by a clean sterile scalpel blade and style and stigma were cut off and discarded. The isolated whole ovaries were cultured horizontally on the prepared media so that the explant basal cut surface had some direct contact with the culture medium. For the expermints 3 and 4, explants were ovary-derived callus obtained from experiments 1 and 3 , respectively.

\subsection{Regeneration Experiments}

Experiment 1: Investigating effect of 2,4-D and NAA on callogenesis and regeneration from ovary explant (induction of EC)

The dissected whole ovaries were cultured on MS medium modification No.1 containing NAA at 0.5, 2.7, $5.4,10.8,16.1,21.5$ and $27 \mu \mathrm{M}$ and 2,4-D at $0.45,2.3,4.5,9,13.5,18$ and $22.5 \mu \mathrm{M}$, individually. The experiment was conducted in a completely randomized design (CRD) with 14 treatments replicated five times, each replication consisted of five explants cultured in a $200 \mathrm{ml}$ jar containing $25 \mathrm{ml}$ of the culture medium. 
Experiment 2: Investigating effects of BA, TDZ and high NAA on ovary explant callogenesis (induction of EC)

The dissected whole ovaries were cultured on MS medium modification No. 2 containing BA at 22.2, 44.4 and $66.6 \mu \mathrm{M}, \mathrm{TDZ}$ at $0.45,2.3,4.5$ and $9 \mu \mathrm{M}$, and NAA at 27, 40.5 and $54 \mu \mathrm{M}$, individually. The experiment was conducted in a CRD with ten growth regulator treatments and five replicates, each replication consisted of five to six explants cultured in a $200 \mathrm{ml}$ jar containing $25 \mathrm{ml}$ of the culture medium.

Experiment 3: Investigating effects of NAA, IBA and IAA on proliferation of ovary-derived callus (maintenance of EC)

From the experiment 1, those ovary explants that had become swollen and voluminous, and produced calli, were transferred onto MS modification No.1 media. The media were supplied with NAA at 27, 40.5 and $54 \mu \mathrm{M}$ alone, NAA at 27 and $40.5 \mu \mathrm{M}$ each in combination with IBA at $12.3 \mu \mathrm{M}$, and NAA at $27 \mu \mathrm{M}$ combined with $12.3 \mu \mathrm{M}$ IBA plus $14.3 \mu \mathrm{M}$ IAA. A PGR-free medium was also included as control. The experiment was conducted in a CRD with seven treatments and five replicates, each replication consisted of four to five explants cultured in a $200 \mathrm{ml}$ jar containing $35 \mathrm{ml}$ of the culture medium.

Experiment 4: Investigating effects of $\mathrm{GA}_{3}, \mathrm{BA}$ and sucrose on development and regeneration of somatic embryo from ovary-derived callus and PEMs (induction and development of somatic embryo)

Proliferated calli and somatic PEMs obtained from the experiment 3, were transferred onto MS modification No.2 medium supplemented with 30 and $70 \mathrm{~g} \mathrm{I}^{-1}$ sucrose, each containing $\mathrm{GA}_{3}$ at $0,1.45$ and $2.9 \mu \mathrm{M}$, and also onto the same basal medium but with $30 \mathrm{~g} \mathrm{I}^{-1}$ sucrose and BA at $0.9,4.44$ and 22.2 $\mu \mathrm{M}$. The experiment was conducted in a CRD with nine growth regulator treatments and four replicates, each replication consisted of seven to eight explants cultured in a $200 \mathrm{ml}$ jar containing $35 \mathrm{ml}$ of the culture medium.

\subsection{Record of observations and statistical data analysis}

In order to record experimental observations, status of explants in different treatments was investigated accurately in terms of growth, development and proliferation of callus, organ, proembryo masses and somatic embryo, eight weeks after culture initiation. Callogenesis percentage was calculated according to ratio of callus-producing explants to the total number of cultured explants. Percentages of explant survival, proliferated explants, and secondary callus proliferation were calculated in the similar way. Mean comparison for these traits was performed using Duncan's multiple range test (DMRT) at $5 \%$ probability level. Quantity of produced or proliferated callus, scaling poor to Excellent, as well callus texture and color, were evaluated visually, scored and recorded descriptively. Organogenesis and SE responses in every treatment and replication were carefully observed using photographs taken by a high quality digital camera and recorded descriptively.

\section{Results And Discussion}


A research study was performed with four individual experiments to investigate and evaluate responses of desert teak ovary explants to various PGRs and also sucrose concentrations in in vitro culture medium and to uncover their probable potentiality in induction of SE.

\subsection{In vitro ovary morphogenesis under influence of 2,4-D and NAA}

As it is evident from Table 1, NAA showed obvious and significant superiority over 2,4-D in callus induction almost in all the concentrations tested. Cent percent callogenesis was achieved with $2.7 \mu \mathrm{M}$ NAA though generally there were no significant differences among most of the NAA levels. However, the best callus induction were in the range of 2.7 to $21.5 \mu \mathrm{M}$. The most suitable 2,4-D concentration inductive of maximum callusing was $0.45 \mu \mathrm{M}$, the lowest level applied. Increasing 2,4-D beyond $0.45 \mu \mathrm{M}$ decreased callus induction drastically so that the callus production was ceased at $\geq 13.5 \mu \mathrm{M}$ totally. The quantity of NAA-induced callus manifested a rising trend with increase in the concentration used. The maximum amount was produced by the ovaries cultured on the medium supplemented with $16.1 \mu \mathrm{M}$ NAA though the concentrations of 10.8, 21.5 and $27 \mu \mathrm{M}$ NAA yielded also high callus amount. Regarding 2,4-D, the callus quantity was assessed as poor with $0.45 \mu \mathrm{M}$ which was dropped to the scale of very poor when the concentration was raised up to $9 \mu \mathrm{M}$. Enhancing 2,4-D level beyond $9 \mu \mathrm{M}$ suppressed callogenesis entirely.

Considering callus texture and color, all NAA concentrations as well as 2,4-D at $0.45 \mu \mathrm{M}$ caused light green friable callus. Such calli were recognized as competent ones for SE (Fig. 1). Those inductive level of 2,4-D levels (above $0.45 \mu \mathrm{M}$ ) resulted in formation of friable callus but brownish in color which are usually unsuitable material to be used for further development particularly for the purpose of SE.

Apart from the dominant response of callogenesis, observations revealed some evidence of SE occurrence, eight weeks after the culture initiation, but only with NAA supplemented media. NAA at 5.4 and $10.8 \mu \mathrm{M}$ could induced PEMs at rate of 40 and 20 percent, respectively, exhibiting few somatic embryos at globular stage, while 21.5 $\mu \mathrm{M}$ NAA induced PEMs revealing a larger number of globular stage somatic embryos (Fig. 1 a,b). Surprisingly, nil embryogenesis was noticed with $16.1 \mu \mathrm{M}$ NAA. On the other side, the highest NAA concentration resulted in and unexpected adventitious root induction and development while no visible SE could be traced (Fig. 2). 2,4-D contained media, the inducers of poor callogenesis, made no progress towards any type of morphogenesis.

Overall, the collected data and observations indicated that the best outstanding outcomes can be obtained through application of NAA in the culture medium ranging 5.4 to $21.5 \mu \mathrm{M}$ so that the induced ECs not only are satisfactory in callogenesis quantity and quality, but also exhibit their potential for SE through developing PEMs and globular stage somatic embryos.

Various PGRs mainly auxins and CKs were used for callus induction in tree species (Giri et al., 2004). Auxins are the key plant PGRs that control in vitro morphogeneis including SE (Cook et al., 1993; Hazubska-Przybył et al., 2020). In general, the most commonly route for inducing SE is through initial exposure of cultures to a medium containing higher doses of auxins, which in most cases leads to 
formation of EC, followed by subsequent transfer to a medium either devoid of auxin, with drastic reduction of auxin concentration or supplemented with optimal levels of CKs (Mithila et al., 2003; Fehér et al., 2001; Isah, 2016; Feher et al., 2002). However, some species tend to express SE even on auxin contained medium, the same medium used as their embryogenesis induction medium (Adil et al., 2018; Isah, 2016). According to Kawahara and Komamine (1995), exogenous auxins play role in gene expression at the early stages of SE.

Here, in the first experiment, 2,4-D and NAA as auxin sources in the culture medium were tested for induction of EC and SE. The results revealed superiority of NAA over 2,4-D in the the concentration range applied. Meanwhile, there are numerous reports on woody as well as herbaceous species that support superiority of one or efficiency of both of these auxins in induction of direct or indirect (callus-mediated) SE.

A report by Xu et al. (2019) showed successful induction of direct SE on different explants of Ranunculus sceleratus by using high concentration of NAA $\left(10 \mathrm{mg} \mathrm{I}^{-1}=54 \mu \mathrm{M}\right)$. In another study, in order to regenerate Fraxinus mandshurica through indirect SE, Liu et al. (2020) found increasing percentage of EC induction on $1 / 2$-strength MS medium containing only low NAA ranging 0 to $0.15 \mathrm{mg} \mathrm{l}^{-1}(\sim 0.75 \mu \mathrm{M})$. Recently, it has been shown that auxin type (2,4-D, NAA and picloram) had no significant effect on embryonic tissue initiation in two spruce species, but the same report has illustrated significantly better EC quantity with NAA than 2,4-D in Picea abies but not for P. omorika (Hazubska-Przybył et al., 2020). My results are fully in agreement with these findings, emphasizing the prominent role of NAA in promotion of process of SE. In the study of Bonneau et al. (1994) on induction of SE in European spindle tree, expression of SE was only observed in the presence of NAA or IAA in the induction medium. They affirmed no somatic embryos were observed in the absence of a CK or in the presence of 2,4-D or IBA. In accordance with their results, here also ovary explants did not respond positively to 2,4-D.

Nevertheless, if 2,4-D would be used at still lower concentrations, or alternatively, the duration of explant incubation to the 2,4-D contained medium would be shortened (preferably less than 4 weeks), this auxinic herbicide might appear inductive of SE in Tecomella Undulata. There are also numerous reports supporting highly positive influential effect of 2,4-D in inducing SE (Lambardi, 2000; Fehér et al., 2001, 2002; Singh and Chand, 2003; Sathyanarayana et al., 2004). Studies have shown that exogenously applied 2,4-D can regulate and increase the level of endogenous auxin, which results in an increase in cell division and the establishment of a hormonal gradient that is optimal for the induction of embryogenesis from the somatic cells of treated explants (Cook et al., 1993, Hazubska-Przybył et al., 2020). But the critical point to succeed in the process is to discover the best inductive concentration(s) of 2,4-D for each specific genotype. In Terminalia chebula Retz. the frequency of callus induction from mature zygote embryos was less and non-embryogenic when auxins (2,4-D, NAA, IBA) were used singly in the medium (Anjaneyulu and Giri, 2018). Compared to the present results, this finding is true with respect to 2,4-D but not for NAA. 
Successful protocols for induction of SE using a combination of 2,4-D and a cytokinin (kinetin or BA) have also been previously reported with nodal segments of Santalum album (Peeris and Senarath, 2015), immature zygotic embryos of Alnus glutinosa (Corredoira et al., 2013), cotyledon explants (Singh and Chand, 2003) of Dalbergia sissoo, and anthers and ovaries of several Vitis species (Martinelli et al. 2003; Gambino et al. 2007; Gambino et al. 2021). Similarly, there are also reports showing that a combination of NAA and a cytokinin (kinetin or BA) was inductive of EC in woody species such as Azadirachta indica (Sue et al., 1997), Hardwickia binata (Das et al., 1995) and Quercus suber (Fernandez-Guijarro et al., 1995). Discrepancy between these results and my findings refer to the differences in species genetic makeup, explant type, season of explant collection, mother tree age and its growing conditions, and other factors that could affect explant's endogenous phytohormones levels.

Increase in endogenous auxin content of cells during primary stages of SE has been well-documented (Fehér et al., 2001; Tran et al., 2016). Hence, employing exogenously supplied auxin through culture medium has been practiced routinely to gain somatic embryos from various explants types in a wide variety of plant species. However, many of these attempts have failed since both the endogenous auxin level, and its exogenous application can be considered as critical factors during the induction and expression of SE. Two mechanisms have been considered as the logic behind such failures; firstly, a critical level of endogenous auxin in cells may be necessary for embryogenesis. Any auxin exogenously supplied would then increase the auxin level in the cells above this critical level can lead to inhibition of embryogenesis. Secondly, a polarized distribution of endogenous auxin in the cells may be essential for embryogenesis. Disturbance of the polarized distribution of endogenous auxin in the cell clusters or callus tissue by an inappropriate exogenous auxin would then inhibit the action of endogenous auxin and cause inhibition of embryo formation (Fujimura and Komamine, 1979; Cook et al., 1993; Fehér et al., 2001).

In a research article by Patel and Patel (2013) on callus induction in internodal explants of Tecomella undulata (desert teak), both NAA and 2,4-D individually at 2.5-3 $\mathrm{mg} \mathrm{I}^{-1}$ induced good callogenesis mostly with friable texture. Their results are partially in agreement with the present results. The most likely reason for unresponsiveness/poor response of the ovary explants to 2,4-D in induction of EC, could be supra-optimal concentrations of 2,4-D added to the induction media. The present results suggest that 2,4$D$ at less than $0.45 \mu \mathrm{M}$ might be highly inductive of callogenesis in ovary explants. Another alternative is the use of a cytokinin like kinetin at relatively low concentrations in combination with 2,4-D. There was no report of SE by Patel and Patel (2013). Apart from genotypic difference, it seems the explant type used in the two studies had a crucial role in achieving SE. There has been a dominant assumption for a long time that auxin is produced exclusively in young growing parts, such as leaves, flowers and root tips, and is delivered to action sites by a combination of long distance transport and short cell-to-cell polar auxin transport. However, Robert et al. (2015) highlighted the importance of local auxin biosynthesis for reproductive organ and embryo development processes. According to them, local auxin biosynthesis occurs in very few cells in specific developmental windows in stamens, gynoecia, ovules and embryos. These recently detected sources of auxin influence the flow of auxin within the reproductive tissues and 
embryos, and thus the formation of auxin gradients which play key roles in organ morphogenesis. Therefore, local auxin biosynthesis might be an upstream component and trigger of all auxin-mediated developmental programs. Keeping these facts in the mind, ovary explants are logically richer in auxin content compared to other vegetative tissue-originated explants especially those which are not known to be auxin producing plant parts such as mature internodal segment explants used by Patel and Patel (2013). Therefore, we can strongly assume that ovary explant possesses more cells capable of SE.

Previously Tarre et al. (2004) illustrated that SE and adventitious root initiation had a common origin histologically. The findings obtained in the present experiment is highly compatible with theirs, confirming positive effect of relatively high NAA in inducing SE as well as initiating adventitious rooting. Occurrence of adventitious rooting during SE induction using an auxin-fortified medium have also been reported earlier in several species such as Dalbergia sissoo (Singh and Chand, 2003), Olea europaea (Pires et al., 2020) and Koelreuteria paniculata (Yang et al., 2018). This phenomenon uncovers that fact that non optimal concentration(s) and type of auxin in culture medium could divert partially or totally the SE path within the explant.

\subsection{Ovary callogenesis affected by BA, TDZ and high NAA}

In order to know how ovary explant respond to CKs, BA and TDZ were used as medium supplements at different concentrations. NAA was also tested at higher concentrations to find out perception of the explant response at elevated levels. BA induced callogenesis at rate of 47 to 94 percent and the best concentration was found $44.4 \mu \mathrm{M}$ (Table 2). Similarly, TDZ was able to induce callusing in the whole range used. Increase in TDZ level resulted in significant decline in the callogenesis rate. The cent percent callogenesis was achieved with $0.45 \mu \mathrm{M}$ TDZ though not significantly different from that obtained with $44.4 \mu \mathrm{M}$ BA. NAA applied at concentrations as high as 27 to $54 \mu \mathrm{M}$, yielded the poorest callus induction compared to both CKs used.

Raising BA level from 22.2 to $66.6 \mu \mathrm{M}$ reduced callus quantity drastically. The same trend was also observed with TDZ. While in the first experiment the highest callus quantity was achieved in the range of 10.8 to $21.5 \mu \mathrm{M} \mathrm{NAA}$, here the callus quantity reduced to the scale of moderate even poor by the rise in NAA level to $27 \mu \mathrm{M}$ and more.

Regenerated calli by all the three PGRs had compact texture. Callus color varied from light to dark brown for BA supplemented media, brownish green to dark brown for TDZ and light brown to brownish green for NAA. The common feature observed with all three PGS was that, the higher concentration of the PGS in the medium, the darker the callus color became. Taking into account all callogenesis traits, the medium fortified with $0.45 \mu \mathrm{M}$ TDZ was concluded as the best inductive treatment. Altogether, though the best callogenesis was obtained with TDZ at low concentrations but none of the treatments, neither the CKs nor NAA, could bear EC as there was no sign of formation of PEMs or pre-embryos. Another tip that led us to this conclusion was the fact that somatic embryos mostly originate from soft friable callus (Matsuoka and Hinata, 1979) or granular, white or yellow calli (Gambino et al., 2021) which was not observed in this experiment. Therefore, the whole induced calli were considered as non-embryogenic. 
CKs are a group of phytohormones derived from adenine, which consist of a variety of molecular structures. The most abundant CKs in plants are adenine-type species (Li et al., 2021). As mentioned above, apart from auxins, various CKs both natural and synthetic including BA, Kinetin, TDZ, 2iP and Zeatin have been used for callus induction in numerous tree species (Giri et al., 2004). In Tecomella undulata, previously, profuse callusing with fewer shoot buds per explant was announced by Tiyagi and Tomar (2013), Rastgoo (2014) and Chhajer and Kalia (2017) who tried to propagate it through in vitro organogenesis pathway using BA.

TDZ, a substituted phenylurea compound with strong cytokinin-like activity, originally used as a cotton defoliant (Dinani et al., 2018), has received remarkable attention as a potent regulator of explant morphogenesis in in vitro regeneration systems and been used in a wide variety of plants (Huetteman and Preece, 1993; Lu, 1993, Dinani et al., 2018). Reviewing literature manifests that TDZ has proved to be a great inducer of a diverse array of cultural responses ranging from induction of callus to formation of somatic embryos in a wide range of plant species including both herbaceous and woody species (Murthy et al., 1998, Huetteman and Preece, 1993, Lu, 1993, Dinani et al., 2018). Murthy et al. (1998) listed a number of species stimulated for in vitro SE through inclusion of TDZ in the culture media. TDZ is a substitute for the auxin/cytokinin requirement that is needed during SE, thereby increasing the number of formed somatic embryos (Murthy et al., 1998, Dinani et al., 2018). There are numerous reports showing employment of TDZ for SE in many woody species such as white ash, eastern black walnut, Rubus, and Vitis vinifera (Huetteman and Preece, 1993), Azadirachta indica (Murthy and Saxena, 1998), Coffea spp. (Giridhar et al., 2004), and blueberry (Vaccinium corymbosum $\times$ V. angustifolium) cultivars (Ghosh et al., 2018). Several reports indicated TDZ at very low levels could induce direct SE (Qureshi and Saxena, 1992; lantcheva et al., 1999; Lin et al., 2004). Chhajer and Kalia (2017) found addition of TDZ in the culture medium unsuitable for shoot multiplication of $T$. undulata as it led to proliferation of excessive callus. Despite difference in explant type (nodal segment used by them), profuse callus-inducing properties of TDZ is a common feature between Chhajer and Kalia's results and the results of the present work. TDZ has also been capable of shoot organogenesis in various species (Lu, 1993; Dinani et al., 2018).

Higher levels of CKs are known to induce programmed cell death in cell cultures (Carimi et al., 2003). CKs are also known to enhance biosynthesis of ethylene (Abeles et al., 1992) thereby applying them at relatively high levels can adversely affect the growth of cultures and lead towards aging. Testing lower concentrations of this PGRs category might bear positive results.

\subsection{Auxins influenced callus proliferation and triggered SE variably}

Upon successful induction, ECs continue to grow to produce new masses when regularly subcultured on fresh maintenance medium amended with auxins or CKs at lower or same concentration to the induction medium till cultures are established (Isah, 2016). Hence, in order to gain sufficient EC for the next step viz. induction of somatic embryos, as well as evaluating response of NAA-induced ECs to a wider range of auxins, the ECs produced using low NAA, were transferred onto the media containing NAA, IBA and IAA at variable concentrations and combinations. A PGR-free medium was also included as the control. The 
results have been displayed in Table 3. The highest explant survival rates were recorded in the medium devoid of PGR $(80 \%)$ and the media containing $40.5 \mu \mathrm{M}$ NAA with and without $12.3 \mu \mathrm{M} \mathrm{IBA}(77.7 \%$ and $66.7 \%$, respectively). The percentage of proliferated explants recorded the highest values in the media with 40.5 and $27 \mu \mathrm{M}$ NAA, each combined with $12.3 \mu \mathrm{M}$ IBA (77.7\% and $56.3 \%$, respectively). The medium containing $54 \mu \mathrm{M}$ NAA alone showed the lowest figures for both explant survival rate and proliferation rate.

Having looked at the quantity of callus proliferation, the best results belonged to the media with NAA alone $(40.5 \mu \mathrm{M})$ as well as with NAA + IBA $(27+12.3) \mu \mathrm{M}$. Callus texture was friable in the control as well as the medium with $27 \mu \mathrm{M}$ NAA alone whereas the remaining media proliferated compact callus. Callus color was light green to light yellow or lemon-colored in almost all the media excepting the medium fortified with NAA $54 \mu \mathrm{M}$ that changed the color slightly brownish.

Apart from callus proliferation, some embryogenic cases were observed in some of the media. The control treatment protruded several individual yellow-colored globular and heart-shaped somatic embryos in a few explants (Fig. 3a). All those media contained NAA alone, exhibited development of PEMs and revealed numerous greenish/yellowish globular and heart-shaped somatic embryos in most of their survived explants (Fig. 3b). The strongest demonstration of SE was observed with $54 \mu$ M NAA that could induce and develop a high number of globular and heart-shaped embryos, up to 34 somatic embryos per explant in some cultures.

Combination of IBA and IAA with NAA, in the concentrations used here, had inhibitory effect on induction and development of somatic embryos in the proliferated EC so that it could be inferred, cautiously, both IBA and IAA might have negative impact on somatic embryo formation in this species under the conditions prevailing in this research. Previously, similar comment about negative impact of IBA in culture media on somatic embryo induction in European spindle tree has been reported by Bonneau et al. (1994).

Overall, a conclusion drawn from this experiment is that, for the purpose of proliferation of friable EC, the PGR-free medium is the best choice. This outcome is in accordance with some earlier reports (Adil et al., 2018; Hernandez et al., 2003; Mauri and Manzanera, 2005; Estabrooks et al., 2007; Fernandez-Guijarro et al., 1995). In the meantime, looking for induction of SE led to the medium containing $54 \mu \mathrm{M}$ NAA alone. However, a scrutinized look on the results disclosed that the medium received $40.5 \mu \mathrm{M}$ NAA could also yield an intermediate output as it showed reasonable rates of explant survival and callus proliferation as well as satisfactory percentage of embryo development. Announcing NAA as a suitable growth regulator for proliferation of embryogenic tissue has been previously mentioned in some other species such as Picea abies (Hazubska-Przybył et al., 2020) and Fraxinus mandshurica (Liu et al., 2020).

While in this experiment the satisfactory proliferation of EC as well as somatic embryo development was obtained in the medium containing 40.5 $\mu$ M NAA, Corredoira et al. (2013) introduced MS medium supplemented with a cytokinin $(0.44 \mu \mathrm{M} \mathrm{BA})$ as the best proliferation medium for induction of secondary somatic embryos in alder tree (Alnus glutinosa). They also found that adding NAA $(0.54 \mu \mathrm{M})$ to the medium, dropped secondary embryogenesis coefficient significantly. Similarly, Valladares et al. (2006) 
and Mallo'n et al. (2012) maintained embryogenic lines of mature oak trees (Quercus robur) on MS medium supplemented with $0.44 \mu \mathrm{M}$ BA and $0.27 \mu \mathrm{M}$ NAA. Such distinct and even contradictory results can only be interpreted by considering all probable internal and external factors that influence the endogenous hormonal balance of the explant employed for each species. It is, therefore, important to find a reliable formula for culture medium composition, particularly with respect to PGRs, that can support proliferation of the already produced EC which in turn needed to ensure sufficient availability of explant material for induction of somatic embryos at the next phase, concurrently insuring maintenance of its embryogenic potential which is even of higher importance.

\subsection{Low BA positively affected further development of the ECs}

In order to advance SE and development of PEMs and early stages somatic embryos into mature somatic embryos, the proliferated ECs obtained during the experiment 3 carrying embryonic structures, were transferred onto MS modification No.2 medium devoid of growth regulator (Control), and also onto the media supplemented with $\mathrm{GA}_{3}$ and $\mathrm{BA}$ at different concentrations individually. Sucrose was also tested at two levels; standard and high dose $\left(30\right.$ and $\left.70 \mathrm{~g} \mathrm{I}^{-1}\right)$ when $\mathrm{GA}_{3}$ was used as the sole source of PGR.

According to Table 4, the media containing $30 \mathrm{~g} \mathrm{I}^{-1}$ sucrose whether with no PGR or with $\mathrm{GA}_{3}(1.45$ and $2.9 \mu \mathrm{M})$ could not advance the path of SE and did not yield any promising outcomes. There are reports with similar results of inhibitory effects of $\mathrm{GA}_{3}$ in somatic embryo formation and subsequent development in some other systems (Chen et al., 2010; Hutchinson et al., 1997). However, the stimulatory effect of $\mathrm{GA}_{3}$ in somatic embryo induction, formation or germination has also been reported in other species like Medicago sativa (Rudus et al., 2000), Cocos nucifera (Montero-Co'rtes et al., 2010). While a supporting report of Rudus et al. (2000) theorized that the level of endogenous GAs is presumably sufficient for callus induction and growth but not optimal for the induction and particularly for the differentiation of embryos, an opposing report by Hutchinson et al. (1997) concluded that the presence of GAs during both the induction and expression phases of SE was significantly detrimental to somatic embryo formation. It seems species- as well as explant-dependent endogenous hormonal balance especially intrinsic content of gibberellins would ultimately determines the need or no need for using exogenous gibberellins in the developmental phases of SE process.

Regardless of $\mathrm{GA}_{3}$ concentration, elevating sucrose level to $70 \mathrm{~g} \mathrm{I}^{-1}$ not only did not improve further development of EC but also paralyzed explant response entirely, ceased the minute callus proliferation which occurred with $30 \mathrm{~g} \mathrm{I}^{-1}$ sucrose, absolute failure was observed and the explants degenerated gradually. This result is contradictory to Dennis Thomas's report (2006) that showed beneficial influence of $200 \mathrm{mM}\left(\sim 70 \mathrm{~g} \mathrm{I}^{-1}\right)$ sucrose incorporated into the $\mathrm{GA}_{3}$-supplemented medium in embryogenesis response of Tylophora indica.

CKs have been shown to promote secondary SE in several woody species (Jime'nez 2005). Fortifying the media with BA at low concentrations $(0.9$ and $4.44 \mu \mathrm{M})$ led to recurrent callus proliferation and more importantly induction of secondary SE in a number of the explants (Fig. 4a). Quantity of newly 
proliferated callus with the low levels of BA was assessed as good to excellent, exhibiting light green to brownish color and compact texture. Raising BA level to $22.2 \mu \mathrm{M}$ though maintained callus proliferation status (Fig. 4b) but inhibited occurrence of secondary SE which was observed at low concentrations.

The ultimate encouraging conclusion drawn from this experiment was that for the goal of maintenance of SE capability of the beforehand produced ECs, the optimum medium is the one that its sucrose level is kept at $30 \mathrm{~g} \mathrm{I}^{-1}$ and supplemented with BA in the range of $0.9-4.44 \mu \mathrm{M}$. This conclusion is in agreement with that of Corredoira et al. (2013) with embryogenic lines of Alnus glutinosa and Liu et al. (2020) with cotyledon-derived EC of Fraxinus mandshurica. Substitution of sucrose by other carbohydrate sources or osmotic agents has been proposed as an effective alternative tool for pushing forward SE process for some species not responding satisfactorily with sucrose (Santos et al., 2002).

\section{Conclusion}

The present research was performed as the first-ever step towards induction of in vitro SE in desert teak. Auxin type and concentration are greatly determinant for successful induction of EC in this recalcitrant species. NAA at low concentrations was the best inducer of EC in ovary explant. Although 2,4-D failed to promote $\mathrm{SE}$, but manipulation of its concentration for less than $0.45 \mu \mathrm{M}$, shortening explant exposure period, and/or its application in combination with a CK are viable alternatives suggested for future studies. Both the CKs tried, BA and TDZ, failed to induce EC. But more exploration on probable capability of TDZ in micropropagation of this species my end to desirable results. NAA up to $40.5 \mu \mathrm{M}$ was observed a suitable stimulator for proliferation of the EC induced by itself. However, PGR-free medium was also found satisfactory in this respect. While $\mathrm{GA}_{3}$ revealed inhibitory effect on embryo development and maturation, BA acted positively though was unable to develop the embryos to the cotyledonary stage. Therefore, more investigations should be tried to optimize a hormonal formula for this phase. Raising sucrose to $70 \mathrm{~g} \mathrm{I}^{-1}$ degenerated EC, PEMs and early stage somatic embryos. The promising findings achieved in the present study can be a good backbone for further research works. To the best of my knowledge, this is the first research study undertaken in the ground of micropropagation of desert teak through SE and also it is for the first time that potency of a reproductive organ is exploited as an explant in micropropagation of Tecomella undulata. Nevertheless, further research works are still necessary to keep on optimizing in vitro conditions for creation of a perfect protocol of SE for this precious endangered species.

\section{Abbreviations}

MS: Murashige and Skoog Medium, 1962

NAA: a-naphthalene acetic acid

2,4-D: 2,4-dichlorophenoxyacetic acid 
BA: $\mathrm{N}^{6}$-Benzyladenine

TDZ: Thidiazuron

IBA: Indole-3-butyric acid

IAA: Indole-3-acetic acid

$\mathrm{GA}_{3}$ : Gibberellic acid

CKs: Cytokinins

SE: Somatic embryogenesis

EC: Embryogenic callus

PEMs: Pro-embryogenic masses

PGRs: Plant Growth Regulators

\section{Declarations}

Funding 'Not applicable'

Conflicts of interest/Competing interests 'Not applicable'

Availability of data and material (data transparency) 'Not applicable'

Code availability (software application or custom code) 'Not applicable'

Ethics approval (include appropriate approvals or waivers) 'Not applicable'

Consent to participate (include appropriate statements) 'Not applicable'

Consent for publication (include appropriate statements) 'Not applicable'

The Orcid-ID (Corresponding author) https://orcid.org/0000-0001-7354-6168

\section{Data Availability Statement}

The datasets generated during and/or analyzed during the current study are available from the corresponding author on reasonable request.

\section{Author contribution statement}

All research works including planning, performing, data collection and analysis, results interpretation, manuscript writing and revising was done by the sole author of the presented manuscript. 


\section{References}

1. Abeles FB, Morgan PW, Salveit M (1992) Ethylene in plant biology. 2nd ed., Academic Press, New York

2. Adil M, Kang DI, Jeong BR (2018) Data on recurrent somatic embryogenesis and in vitro micropropagation of Cnidium officinale Makino. Data in Brief 19: 2311-2314. https://doi.org/10.1016/j.dib.2018.07.013

3. Agrawal DC, Gebhardt K (1994) Rapid micropropagation of hybrid willow (Salix) established by ovary culture. J Plant Physiol 143: 763-765.

4. Ahmad F, Khan RA, Rasheed S (1994) Preliminary screening of methanolic extracts of Celastrus paniculatus and Tecomella undulata for analgesic and anti-inflammatory activities. Ethnopharmacol 42: 193-198.

5. Ammirato PV (1983) Embryogenesis. In: Evans DA, Sharp WR, Ammirato PV \& Yamada Y (Eds) Handbook of Plant Cell Culture, Vol 1 (pp 82-123). MacMillan Publishing Company, New York

6. Anjaneyulu C, Giri CC (2018) Biochemical characterization of somatic embryogenesis and genetic transformation studies in Terminalia chebula Retz.: An immensely valuable medicinal tree. Ann Phytomed 7(1): 38-51. https://doi.org/10.21276/ap.2018.7.1.5

7. Aslam M, Singh R, Anandhan S, et al. (2009) Development of a transformation protocol for Tecomella undulata (Smith) Seem from cotyledonary node explants. Sci Hortic 121: 119-121

8. Bhagyalakshmi N (1999) Factors influencing direct shoot regeneration from ovary explants of saffron. Plant Cell Tiss Org Cult 58: 205-211. https://doi.org/10.1023/A:1006398205936

9. Bonneau L, Beranger-Novat N, Monin J (1994) Somatic embryogenesis and plant regeneration in a woody species: the European Spindle Tree (Euonymus europaeus L.). Plant Cell Rep 13:135-138

10. Carimi F, Zottini M, Formentin E, Terzi M, Lo Schiavo F (2003) Cytokinins: new apoptotic inducers in plants. Planta 216:413-421

11. Chal J, Kumar V, Kaushik S (2011) A Phytopharmacological overview on Tecomella undulata G. Don. J App Pharm Sci 1: 11-12

12. Chen AH, Yang JL, Niu YD et al. (2010) High-frequency somatic embryogenesis from germinated zygotic embryos of Schisandra chinensis and evaluation of the effects

of medium strength, sucrose, GA3, and BA on somatic embryo development. Plant Cell Tiss Organ Cult 102: 357-364. https://doi.org/10.1007/s11240-010-9740-6

13. Chhajer S, Kalia RK (2017) Seasonal and micro-environmental factors controlling clonal propagation of mature trees of marwar teak [Tecomella undulata (Sm.) Seem]. Acta Physiol Plant 39:60. https://doi.org/10.1007/s11738-017-2364-2

14. Cook TJ, Racusen RH, Cohen JD (1993) The Role of Auxin in Plant Embryogenesis. The Plant Cell 5(11): 1494-1495. https://doi.org/10.1105/tpc.5.11.1494

15. Corredoira E, Ballester A, Ibarra M, et al. (2015) Induction of somatic embryogenesis in explants of shoot cultures established from adult Eucalyptus globulus and $E$. 
saligna $\times$ E. maidenii trees. Tree Physiol 35: 678-690. https://doi.org/10.1093/treephys/tpv028

16. Corredoira E, Valladares S, Martínez MT, et al. (2013) Somatic embryogenesis in Alnus glutinosa (L.) Gaertn. Trees 27: 1597-1608. https://doi.org/10.1007/s00468-013-0907-8

17. Das AB, Rout GR, Das $P$ (1995) In vitro somatic embryogenesis from callus culture of the timber yielding tree Hardwickia binata Roxb. Plant Cell Rep 15:147-149

18. Dennis Thomas T (2006) Effect of Sugars, Gibberellic Acid and Abscisic Acid on Somatic Embryogenesis in Tylophora indica (Burm. f.) Merrill. Chin J Biotechnol 22(3): 465-471

19. Dinani, ET, Shukla, MR, Turi, CE, et al. (2018) Thidiazuron: Modulator of Morphogenesis In Vitro. In: Ahmad N, Faisal M (eds.), Thidiazuron: From Urea Derivative to Plant Growth Regulator. Springer Nature Singapore Pte Ltd, pp 1-36. https://doi.org/10.1007/978-981-10-8004-3

20. Estabrooks T, Browne R, Dong Z (2007) 2,4,5-Trichlorophenoxyacetic acid promotes somatic embryogenesis in the rose cultivar 'Livin' Easy' (Rosa sp.). Plant Cell Rep 26:153-160. https://doi.org/10.1007/s00299-006-0231-5

21. Fehér A, Pasternak T, Miskolczi P, et al. (2001) Induction of embryogenic pathway in somatic plant cells. Acta Hortic 560: 293-298. https://doi.org/10.17660/ActaHortic.2001.560.55

22. Fehér $A$, Pasternak T, Otvos $K$, et al. (2002) Induction of embryogenic competence in somatic plant cells: a review. Biol Sect Bot 51(1): 5-12

23. Fernandez-Guijarro B, Celestino C, Toribio M (1995) Influence of external factors on secondary embryogenesis and germination in somatic embryos from leaves of Quercus suber. Plant Cell Tiss Org Cult 41: 99-106

24. Fraga M, Alonso M, Borja M (2004) Shoot Regeneration Rates of Perennial Phlox are Dependent on Cultivar and Explant Type. HortSci 39(6): 1373-1377

25. Fujimura T, Komamine A (1979) Involvement of Endogenous Auxin in Somatic Embryogenesis in a Carrot Cell Suspension Culture. Z. Pjlanzenphysiol 95:13-19

26. Gambino G, Moine A, Boccacci P, et al. (2021) Somatic embryogenesis is an effective strategy for dissecting chimerism phenomena in Vitis vinifera cv Nebbiolo. Plant Cell Rep 40: 205-211. https://doi.org/10.1007/s00299-020-02626-9

27. Gambino G, Ruffa P, Vallania R, et al. (2007) Somatic embryogenesis from whole flowers, anthers and ovaries of grapevine (Vitis spp.). Plant Cell Tiss Organ Cult 90:79-83. https://doi.org/10.1007/s11240-007-9256-x

28. Ghosh A, Igamberdiev AU, Debnath SC (2018) Thidiazuron-induced somatic embryogenesis and changes of antioxidant properties in tissue cultures of half-high blueberry plants. Sci Rep 8:16978. https://10.1038/s41598-018-35233-6

29. Giri CC, Shyamkumar B, Anjaneyulu C (2004) Progress in tissue culture, genetic transformation and applications of biotechnology to trees: an overview. Trees 18:115-135

30. Giridhar P, Kumar V, lindu EP, et al. (2004) Thidiazuron induced somatic embryogenesis in Coffea arabica L. and Coffea canephora P ex Fr. Acta Bot. Croat. 63 (1): 25-33 
31. Goodin JR, Northington DK (1985) Plant resource of arid and semi-arid lands- A global perspective, Academic Press Inc., New York.

32. Guan Y, Li S-G, Fan X-F, et al. (2016) Application of Somatic Embryogenesis in Woody Plants. Front Plant Sci 7:938. https://doi.org/10.3389/fpls.2016.00938

33. Hazubska-Przybył T, Ratajczak E, Obarska A, et al. (2020) Different Roles of Auxins in Somatic Embryogenesis Efficiency in Two Picea Species. Int J Mol Sci 21(9), 3394.

https://doi.org/10.3390/ijms21093394

34. Hernandez I, Celestino C, Toribio M (2003) Vegetative propagation of Quercus suber L. by somatic embryogenesis, I. Factors affecting the induction in leaves from mature cork oak trees. Plant Cell Rep 21:759-764. https:// 10.1007/s00299-003-0605-x

35. Huetteman CA, Preece JE (1993) Thidiazuron: a potent cytokinin for woody plant tissue culture. Plant Cell Tiss Org Cult 33: 105-119

36. Hussain SS, Ahmed M, Siddiqui MF, Wahab M (2010) Threatened and endangered native plants of Karachi. Int J Biol Biotechnol 7(3): 259-266

37. Hutchinson M J, KrishnaRaj S, Saxena PK (1997) Inhibitory effect of GA3 on the development of thidiazuron-induced somatic embryogenesis in geranium (Pelargonium ¥hortorum Bailey) hypocotyl cultures. Plant Cell Reports 16: 435-438

38. Iantcheva A, Vlahova M, Bakalova E, et al. (1999) Regeneration of diploid annual medics via direct somatic embryogenesis promoted by thidiazuron and benzylaminopurine. Plant Cell Rep 18: 904910

39. Isah T (2016) Induction of somatic embryogenesis in woody plants. Acta Physiol Plant 38:118. https://doi.org/10.1007/s11738-016-2134-6

40. Jimenez VM (2005) Involvement of plant hormones and plant growth regulators on in vitro SE. Plant Growth Regul 47(2-3): 91-110. https://doil.org/10.1007/s10725-005-3478-x

41. Joshi KC, Singh P, Pardasani RT (1977) Quinones and other constituents from the roots of Tecomella undulata. Planta Medica 31: 14-16.

42. Kalia RK, Rai MK, Sharma R, et al. (2014) Understanding Tecomella undulata: an endangered pharmaceutically important timber species of hot arid regions. Genet Resour Crop Evol, 61:13971421. https://doi.org/10.1007/s10722-014-0140-3

43. Kawahara R., Komamine A. (1995) Molecular Basis of Somatic Embryogenesis. In: Bajaj Y.P.S. (Ed) Somatic Embryogenesis and Synthetic Seed I. Biotechnology in Agriculture and Forestry, Vol 30, pp. 30-40. Springer, Berlin, Heidelberg. https://doi.org/10.1007/978-3-662-03091-2_3

44. Lambardi M. (2000) Somatic embryogenesis in cypress (Cupressus sempervirens L.). In: Jain S.M., Gupta P.K., Newton R.J. (Eds) Somatic Embryogenesis in Woody Plants. Forestry Sciences, vol 67. Springer, Dordrecht. https://doi.org/10.1007/978-94-017-3030-3_19

45. Li S-M, Zheng H-X, Zhang X-Sh, Sui N. (2021) Cytokinins as central regulators during plant growth and stress response. Plant Cell Rep 40: 271-282. https://doi.org/10.1007/s00299-020-02612-1 
46. Lin Ch-S, Lin Ch-Ch, Chang W-Ch (2004) Effect of thidiazuron on vegetative tissue-derived somatic embryogenesis and flowering of bamboo Bambusa edulis. Plant Cell Tiss Org Cult 76: 75-82

47. Litz RE, Chavez VM, Moon PA (1997) Induction of embryogenic cultures from mature-phase tropical and subtropical trees and control of somatic embryo maturation and germination. In-Proceedings of Recent Advances in Biotechnology for Tree Conservation and Management, Florianópolis, pp. 232243

48. Liu Y, Wei Ch, Wang $\mathrm{H}$, et al. (2020) Indirect somatic embryogenesis and regeneration of Fraxinus mandshurica plants via callus tissue. J For Res 32:1613-1625. https://doi.org/10.1007/s11676-02001199-3

49. Lu C-Y (1993) The use of thidiazuron in tissue culture. In Vit Cell Dev Biol 29: 92-96

50. Malik M (2008) Comparison of different liquid/solid culture systems in the production of somatic embryos from Narcissus L. ovary explants. Plant Cell Tiss Org Cult 94:337-345 https://doi.org/10.1007/s11240-008-9415-8

51. Mallo'n R, Covelo P, Vieitez AM (2012) Improving secondary embryogenesis in Quercus robur: application of temporary immersion for mass propagation. Trees 26: 731-741. https://doi.org/10.1007/s00468-011-0639-6

52. Martinelli L, Gribaudo I, Semenzato M, et al. (2003) Ovary as valuable explant for somatic embryogenesis induction in grapes (Vitis spp.). Acta Hortic 603: 499-504. https://doi.org/10.17660/ActaHortic.2003.603.65

53. Matsuoka H, Hinata K (1979) NAA-Induced Organogenesis and Embryogenesis in Hypocotyl Callus of Solanum melongena L. J Exp Bot 30(116): 363-370

54. Mauri PV, Manzanera JA (2005) Protocol of somatic embryogenesis; Holm oak (Quercus ilex L.). In: Jain SM and Gupta PK (eds.), Protocol for Somatic Embryogenesis in Woody Plants, Springer, Dordrecht, pp. 469-482

55. Meena D, Kant T, Sharma A (2019) Genetic improvement, propagation and conservation efforts for Tecomella undulate, a flagship timber species of the drylands- A Review. Intl J Biotechnol Trends Tech 9(3): 23-37

56. Mithila J, Hall JC, Victor JMR, et al. (2003) Thidiazuron induces shoot organogenesis at low concentrations and somatic embryogenesis at high concentrations on leaf and petiole explants of African violet (Saintpaulia ionantha Wendl.). Plant Cell Rep 21:408-414.

https://doi.org/10.1007/s00299-002-0544-y

57. Montero-Co'rtes M, Sa'enz L, Co'rdova I, et al. (2010) GA3 stimulates the formation and germination of somatic embryos and the expression of a KNOTTED-like homeobox gene of Cocos nucifera (L.). Plant Cell Rep 29:1049-1059. https://doi.org/10.1007/s00299-010-0890-0

58. Murashigue T, Skoog F (1962) A revised medium for rapid growth and bio assays with tobacco tissue cultures. Physiol Plantarum 15(3): 473-497

59. Murthy BNS, Murch SJ, Saxena PK (1998) Thidiazuron: A potent regulator of in vitro plant morphogenesis. In Vitro Cell Dev Biol-PI 34:267-27 
60. Murthy BNS, Saxena PK (1998) Somatic embryogenesis and plant regeneration of neem (Azadirachta indica A. Juss.). Plant Cell Rep 17: 469-475

61. Nandwani D, Sharma R, Ramawat KG (1996) High frequency regeneration in callus cultures of a treeTecomella undulata. Gartenbauwissenschaft, 61(3): 147-150

62. Patel MB, Patel RS (2013) Impact of Plant Growth regulators (PGRs) on callus induction from internodal explants of Tecomella undulata (Sm.) Seem- A Multipurpose Medicinal plants. Int J Scient Res Publ 3(11): 1-3

63. Peeris M, Senarath W (2015). In vitro propagation of Santalum album L. J Natl Sci Found Sri Lanka 43: 265-272. https://doi.org/10.4038/jnsfsr.v43i3.7954

64. Pires R, Cardoso H, Ribeiro A, Peixe A, Cordeiro A (2020) Somatic Embryogenesis from Mature Embryos of Olea europaea L. cv. 'Galega Vulgar' and Long-Term Management of Calli Morphogenic Capacity. Plants 9(6): 758. https://doi.org/10.3390/plants9060758

65. Qureshi JA, and Saxena PK (1992) Adventitious shoot induction and somatic embryogenesis with intact seedlings of several hybrid seed geranium (Pelargonium $\times$ hortorum Bailey) varieties. Plant Cell Rep 11:443-448

66. Raj Bhansali R (1993) Bud culture of shoot multiplication and plantlet formation of Tecomella undulata (Rohida) woody tree of arid zone. Tropic Sci 33: 1-8

67. Raj Bhansali R, Singh M (2000) Somatic embryogenesis in fruit and forest trees of arid zone. In: Jain SM, Gupta PK, Newton RJ (Eds.) Somatic Embryogenesis in Woody Plants, Vol 6. Kluwer Academic Publishers, Dordrecht, Netherlands, pp. 141-168. https://doi.org/10.1007/978-94-017-3030-3

68. Rastgoo S (2016) Response of stamen and pistil of desert teak (Tecomella undulata (Sm.) Seem) to different plant growth regulators in in vitro culture. Proceeding of $9^{\text {th }}$ Iranian National Horticulture Congress, held on 25-28 ${ }^{\text {th }}$ January 2016, at University of Chamran, Ahwaz, Iran.

69. Rastgoo, S. (2014) Feasibility study of clonal propagation of desert teak (Tecomella undulata) through tissue culture and cutting. Research project final report, Directorate of Research, Persian Gulf University, Bushehr, Iran (In Persian)

70. Robert HS, Khaitova LC, Mroue S, Benková E (2015) The importance of localized auxin production for morphogenesis of reproductive organs and embryos in Arabidopsis. J Exp Bot 66(16): 5029-5042. https://doi.org/10.1093/jxb/erv256

71. Robinson R, Kumari B, Beniwal VS (2005) In vitro shoot multiplication of Tecomella undulata (SM.) Seem. - An endangered tree species. Indian J Plant Physiol 10 (4):372-376

72. Roshan Sh, Emtehani MH, Mosleh Arani A, et al. (2011) Desert teak; a species on the verge of extinction (part second). Sonboleh 212: 38-39. (In Persian)

73. Rudus I, Kepczynska E, Kepczynski J. (2000) Regulation of Medicago sativa L. somatic embryogenesis by gibberellins. Plant Growth Regul 36: 91-95.

https://doi.org/10.1023/A:1014751125297 
74. Santos ALW, Silveira V, Steiner N, et al. (2002) Somatic Embryogenesis in Parana Pine (Araucaria angustifolia (Bert.) O. Kuntze). Braz Arch Biol Technol 45(1): 97-106

75. Sathyanarayana BN, Suma GBS, Prashanta KG, et al. (2004) Somatic embryogenesis and plant regeneration from stem, leaf, root and petal explants of sweet type carambola (Avehhoa carambola L.). J Plant Biol 31(2): 131-137

76. Singh AK, Chand S (2003) Somatic embryogenesis and plant regeneration from cotyledon explants of a timber-yielding leguminous tree, Dalbergia sissoo Roxb. J. Plant Physiol. 160. 415-421

77. Srivastava P, Singh M, Mathur P, et al. (2009) In vitro organogenesis and plant regeneration from unpollinated ovary cultures of Azadirachta indica. BIOL PLANTARUM 53(2): 360-364

78. Su WW, Hwang W-I, Kim SY, Sagawa Y (1997) Induction of somatic embryogenesis in Azadirachta indica. Plant Cell Tiss Org Cult 50:91-95

79. Tarre $\mathrm{E}$, Magioli C, Margis-Pinheiro M, et al. (2004) In vitro somatic embryogenesis and adventitious root initiation have a common origin in eggplant (Solanum melongena L.). Revista Brasil Bot, 27(1): 79-84

80. Tran TH, Bui TV, Feng TY (2016) The role of auxin and cytokinin on somatic embryogenesis from cell suspension cultures of the banana cultivar 'Cau Man'. Acta Hortic. 1114: 291-226. https://doi.org/10.17660/ActaHortic.2016.1114.30

81. Tyagi HS, Choudhary GR, Tomar UK (2011) Clonal propagation of an economically important woody tree of the arid zone-Tecomella undulata (Sm.) Seem. Proceeding of $1^{\text {st }}$ Indian Forest Congress held at NAS Complex Pusa, New Delhi on Nov. 22-25, 2011, pp 356-362.

82. Tyagi HS, Tomar UK (2013) Factors affecting in vitro shoot proliferation and rooting of mature Tecomella undulata (Sm.) Seem Tree. Res in Plant Sci 1(2): 38-44

83. Valladares S, Sanchez C, Mart'ınez MT, et al. (2006) Plant regeneration through somatic embryogenesis from tissues of mature oak trees: true-to-type conformity of plantlets by RAPD analysis. Plant Cell Rep 25: 879-886. https://doi.org/10.1007/s00299-005-0108-z

84. Xu K-D, Wang W, Yu D-Sh, et al. (2019) NAA at a high concentration promotes efficient plant regeneration via direct somatic embryogenesis and Se-mediated transformation system in Ranunculus sceleratus. Sci Rep-UK 9:18321. https://doi.org/10.1038/s41598-019-54538-8

85. Yang X, Yang X, Guo T, et al. (2018) High-Efficiency Somatic Embryogenesis from Seedlings of Koelreuteria paniculata Laxm. Forests 9:769. https://doi.org/10.3390/f9120769

86. Zimmerman JL (1993) Somatic embryogenesis: a model for early development in higher plants. The Plant Cell 5:1411-1423

\section{Tables}

Table 1. Regeneration from Desert teak's ovary explant on MS medium modification No.1 supplemented with NAA and 2,4-D eight weeks after culture 


\begin{tabular}{|c|c|c|c|c|c|c|}
\hline \multicolumn{2}{|c|}{$\begin{array}{l}\text { Auxins } \\
(\mu \mathrm{M})\end{array}$} & \multirow{2}{*}{$\begin{array}{l}\text { *Callogenesis } \\
(\%) \\
80 \text { bc }\end{array}$} & \multirow{2}{*}{$\begin{array}{l}{ }^{\star \star} \text { Callus } \\
\text { quantity } \\
+++\end{array}$} & \multirow{2}{*}{$\begin{array}{l}\text { Callus } \\
\text { texture } \\
\text { friable }\end{array}$} & \multirow{2}{*}{$\begin{array}{l}\text { Callus } \\
\text { color } \\
\text { Light green }\end{array}$} & \multirow[t]{2}{*}{$\begin{array}{l}\star \star \star \text { SE/ } \\
\text { Organogenesis }\end{array}$} \\
\hline NAA & 0.5 & & & & & \\
\hline & 2.7 & $100 \mathrm{a}$ & +++ & friable & Light green & \\
\hline & 5.4 & 80 bc & +++ & friable & Light green & $\begin{array}{l}\text { 40\% PEMs with few } \\
\text { GEs }\end{array}$ \\
\hline & 10.8 & $92 \mathrm{ab}$ & ++++ & friable & Light green & $\begin{array}{l}20 \% \text { PEMs with few } \\
\text { GEs }\end{array}$ \\
\hline & 16.1 & $92 a b$ & +++++ & friable & Light green & \\
\hline & 21.5 & $92 a b$ & ++++ & friable & Light green & $\begin{array}{l}20 \% \text { PEMs with } \\
\text { numerous GEs }\end{array}$ \\
\hline & 27.0 & $88 \mathrm{~b}$ & ++++ & friable & Light green & $40 \%$ rhizogenesis \\
\hline \multirow[t]{7}{*}{$\begin{array}{l}2,4- \\
D\end{array}$} & 0.45 & $80 \mathrm{bc}$ & ++ & friable & $\begin{array}{l}\text { Light green to } \\
\text { yellow }\end{array}$ & \\
\hline & 2.3 & $64 \mathrm{~cd}$ & + & friable & $\begin{array}{l}\text { Brownish } \\
\text { green }\end{array}$ & \\
\hline & 4.5 & 40 de & + & friable & Brownish & \\
\hline & 9.0 & 28 ef & + & friable & Brownish & \\
\hline & 13.5 & $0 \mathrm{f}$ & - & & & \\
\hline & 18.0 & $0 \mathrm{f}$ & - & & & \\
\hline & 22.5 & $0 \mathrm{f}$ & - & & & \\
\hline \multicolumn{7}{|c|}{ *Mean having same letter show no significant difference at $P \leq 0.05$ by DMRT. } \\
\hline \multicolumn{7}{|c|}{ **Callogenesis rate; - no callus, + very poor, ++ poor, +++ moderate, ++++ good, +++++ Excellent } \\
\hline 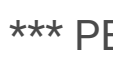 & As: Pro & mbryogenic ma & ses, GEs: C & ar embr & & \\
\hline
\end{tabular}

Table 2. Callus regeneration from Desert teak's ovary explant on MS medium modification No.2 in response to BA, TDZ and high NAA eight weeks after culture 


\begin{tabular}{|c|c|c|c|c|c|}
\hline \multicolumn{2}{|c|}{$\begin{array}{l}\text { Growth regulators } \\
(\mu \mathrm{M})\end{array}$} & $\begin{array}{l}{ }^{*} \text { Callogenesis } \\
(\%)\end{array}$ & ${ }^{\star *}$ Callus quantity & Callus textur & Callus color \\
\hline \multirow[t]{3}{*}{ BA } & 22.2 & $73.3 \mathrm{~b}$ & ++++ & Compact & Light brown \\
\hline & 44.4 & $94.4 \mathrm{a}$ & +++ & Compact & Light brown \\
\hline & 66.6 & $47.2 \mathrm{c}$ & ++ & Compact & Dark brown \\
\hline \multirow[t]{4}{*}{ TDZ } & 0.45 & $100 \mathrm{a}$ & +++++ & Compact & Brownish green \\
\hline & 2.3 & $77.8 \mathrm{~b}$ & ++++ & Compact & Brownish green \\
\hline & 4.5 & $72.2 \mathrm{~b}$ & +++ & Compact & Brownish green \\
\hline & 9.0 & $53.3 \mathrm{c}$ & ++ & Compact & Dark brown \\
\hline \multirow[t]{3}{*}{ NAA } & 27 & $36.4 \mathrm{~cd}$ & +++ & Compact & Light brown \\
\hline & 40.5 & $20.0 d$ & +++ & Compact & Brownish green \\
\hline & 54 & $54.2 \mathrm{c}$ & ++ & Compact & Brownish green \\
\hline \multicolumn{6}{|c|}{ *Mean having same letter show no significant difference at $P \leq 0.05$ by DMRT. } \\
\hline \multicolumn{6}{|c|}{${ }^{\star \star}$ Callogenesis rate; - no callus, + very poor,++ poor,+++ moderate,++++ good,+++++ Excellent } \\
\hline
\end{tabular}

Table 3. Proliferation and somatic embryo induction of ovary-derived callus on MS medium modification No.1 supplemented with different concentrations and combinations of auxins eight weeks after culture intitiation 


\begin{tabular}{|c|c|c|c|c|c|c|c|c|}
\hline \multicolumn{3}{|c|}{$\begin{array}{l}\text { Growth regulators } \\
(\mu \mathrm{M})\end{array}$} & \multirow{2}{*}{$\begin{array}{l}\text { *Explant } \\
\text { survival } \\
(\%)\end{array}$} & \multirow{2}{*}{$\begin{array}{l}\text { *Proliferating } \\
\text { Explant } \\
(\%)\end{array}$} & \multirow[t]{2}{*}{$\begin{array}{l}{ }^{\star *} \text { Callus } \\
\text { quantity }\end{array}$} & \multirow[t]{2}{*}{$\begin{array}{l}\text { Callus } \\
\text { texture }\end{array}$} & \multirow[t]{2}{*}{$\begin{array}{l}\text { Callus } \\
\text { color }\end{array}$} & \multirow[t]{2}{*}{$\star \star \star \star S E$} \\
\hline NAA & IBA & IAA & & & & & & \\
\hline 0 & 0 & 0 & $80.0 \mathrm{a}$ & $53.2 \mathrm{bc}$ & +++ & friable & $\begin{array}{l}\text { Light } \\
\text { green to } \\
\text { light } \\
\text { yellow }\end{array}$ & $\begin{array}{l}20 \% \text { of } \\
\text { explants } \\
\text { with } \\
\text { numerous } \\
\text { yellow GEs }\end{array}$ \\
\hline 27 & 0 & 0 & $55.5 \mathrm{bc}$ & $27.7 \mathrm{~cd}$ & ++ & friable & $\begin{array}{l}\text { Green to } \\
\text { lemon } \\
\text { yellow }\end{array}$ & $\begin{array}{l}75 \% \text { of } \\
\text { explants } \\
\text { with PEMs } \\
\text { and } \\
\text { numerous } \\
\text { yellow GEs }\end{array}$ \\
\hline 40.5 & 0 & 0 & $66.7 \mathrm{ab}$ & $44.0 \mathrm{bcd}$ & ++++ & compact & $\begin{array}{l}\text { Green to } \\
\text { lemon } \\
\text { yellow }\end{array}$ & $\begin{array}{l}75 \% \text { of } \\
\text { explants } \\
\text { with PEMs } \\
\text { and } \\
\text { numerous } \\
\text { green GEs }\end{array}$ \\
\hline 54 & 0 & 0 & $25.0 \mathrm{~d}$ & $25.0 \mathrm{~d}$ & +++ & compact & $\begin{array}{l}\text { Light } \\
\text { green to } \\
\text { brownish }\end{array}$ & $\begin{array}{l}85 \% \text { of } \\
\text { explants } \\
\text { with PEMs } \\
\text { and } \\
\text { numerous } \\
\text { green } \\
\text { globular and } \\
\text { heart-shaped } \\
\text { embryos }\end{array}$ \\
\hline 27 & 12.3 & 0 & $64.5 \mathrm{~b}$ & $56.3 \mathrm{ab}$ & ++++ & compact & $\begin{array}{l}\text { Light } \\
\text { green }\end{array}$ & nil \\
\hline 40.5 & 12.3 & 0 & $77.7 \mathrm{ab}$ & $77.7 \mathrm{a}$ & +++ & compact & $\begin{array}{l}\text { Light } \\
\text { green }\end{array}$ & nil \\
\hline 54 & 12.3 & 14.3 & $44.3 \mathrm{~cd}$ & $44.3 \mathrm{bcd}$ & +++ & $\begin{array}{l}\text { granular } \\
\text { compact }\end{array}$ & $\begin{array}{l}\text { Light } \\
\text { green }\end{array}$ & nil \\
\hline \multicolumn{9}{|c|}{ *Mean having same letter show no significant difference at $P \leq 0.05$ by DMRT. } \\
\hline \multicolumn{9}{|c|}{$\star \star$ Callogenesis rate; - no callus, + very poor, ++ poor,+++ moderate, ++++ good,+++++ Excellent } \\
\hline 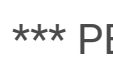 & Is: Prc & ibry & enic mas & GEs: Globul & mbryos & & & \\
\hline
\end{tabular}

Table 4. Response of ovary-derived EC and PEMs ten weeks after transfer onto MS medium modification No.2 supplemented with different levels of sucrose, $\mathrm{GA}_{3}$ and $\mathrm{BA}$ 


\begin{tabular}{|c|c|c|c|c|c|c|c|}
\hline $\begin{array}{l}\text { Sucrose } \\
\left(\mathrm{g} \mathrm{l}^{-1}\right)\end{array}$ & $\begin{array}{l}\mathrm{GA}_{3} \\
(\mu \mathrm{M})\end{array}$ & $\begin{array}{l}\text { BA } \\
(\mu \mathrm{M})\end{array}$ & $\begin{array}{l}{ }^{*} \text { Recurrect } \\
\text { embryogenic } \\
\text { callus } \\
\text { proliferation } \\
(\%)\end{array}$ & $\begin{array}{l}{ }^{\star *} \text { Callus } \\
\text { quantity }\end{array}$ & $\begin{array}{l}\text { Callus } \\
\text { texture }\end{array}$ & $\begin{array}{l}\text { Callus } \\
\text { color }\end{array}$ & $\begin{array}{l}* \star \text { Somatic } \\
\text { embryo } \\
\text { induction }\end{array}$ \\
\hline 30 & 0 & & $6.7 \mathrm{bc}$ & ++ & compact & $\begin{array}{l}\text { Light } \\
\text { green }\end{array}$ & \\
\hline 30 & 1.45 & & $6.7 \mathrm{bc}$ & +++ & compact & $\begin{array}{l}\text { Light } \\
\text { green }\end{array}$ & \\
\hline 30 & 2.9 & & $0 \mathrm{c}$ & - & & & \\
\hline 70 & 0 & & $0 \mathrm{c}$ & - & & & \\
\hline 70 & 1.45 & & $0 \mathrm{c}$ & - & & & \\
\hline 70 & 2.9 & & $0 \mathrm{c}$ & - & & & \\
\hline 30 & & 0.9 & $26.7 \mathrm{ab}$ & ++++ & compact & $\begin{array}{l}\text { Light } \\
\text { green to } \\
\text { brownish }\end{array}$ & $\begin{array}{l}25 \% \text { of } \\
\text { explants } \\
\text { with } \\
\text { numerous } \\
\text { secondary } \\
\text { pre-embryos }\end{array}$ \\
\hline 30 & & 4.44 & $28.3 \mathrm{a}$ & +++++ & compact & $\begin{array}{l}\text { Light } \\
\text { green to } \\
\text { brownish }\end{array}$ & $\begin{array}{l}25 \% \text { of } \\
\text { explants } \\
\text { with } \\
\text { numerous } \\
\text { secondary } \\
\text { pre-embryos }\end{array}$ \\
\hline 30 & & 22.2 & $40.0 \mathrm{a}$ & +++++ & compact & $\begin{array}{l}\text { Light } \\
\text { green }\end{array}$ & \\
\hline \multicolumn{8}{|c|}{ *Mean having same letter show no significant difference at $P \leq 0.05$ by DMRT. } \\
\hline **Calloge & esis sca & $e ;-$ no & + very poor, + & $\mathrm{r},+++\mathrm{mo}$ & rate,++++ & ood, +++++ & xcellent \\
\hline
\end{tabular}

\section{Figures}



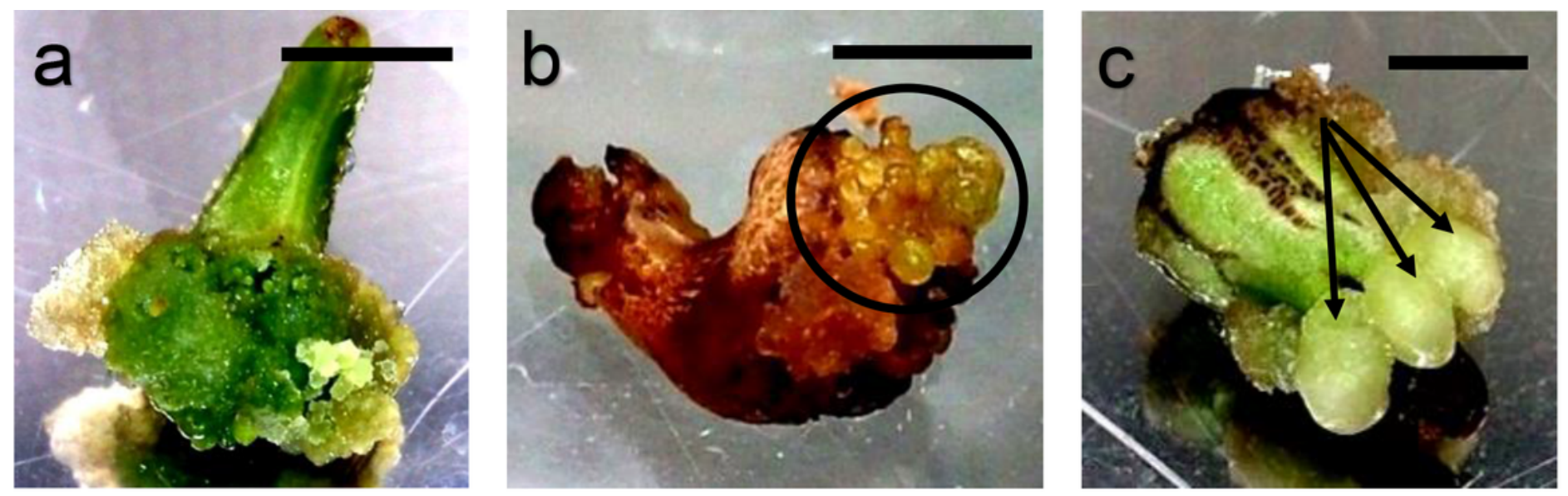

\section{Figure 1}

Morphogenesis of ovary explants 8 weeks after culture initiation in NAA supplemented media. (a) Regeneration of interconnected somatic embryoids from a healthy friable EC produced at the basal end of the explant in the medium with $21.5 \mu \mathrm{M} N A A$, (b) A cluster of globular somatic embryos at the ovary basal end in the medium with $21.5 \mu \mathrm{M} \mathrm{NAA}$, and (c) Development of nodular callus at the ovary stylar end in the medium supplemented with $5.4 \mu \mathrm{M}$ NAA. (Bars $=5 \mathrm{~mm}$ ).
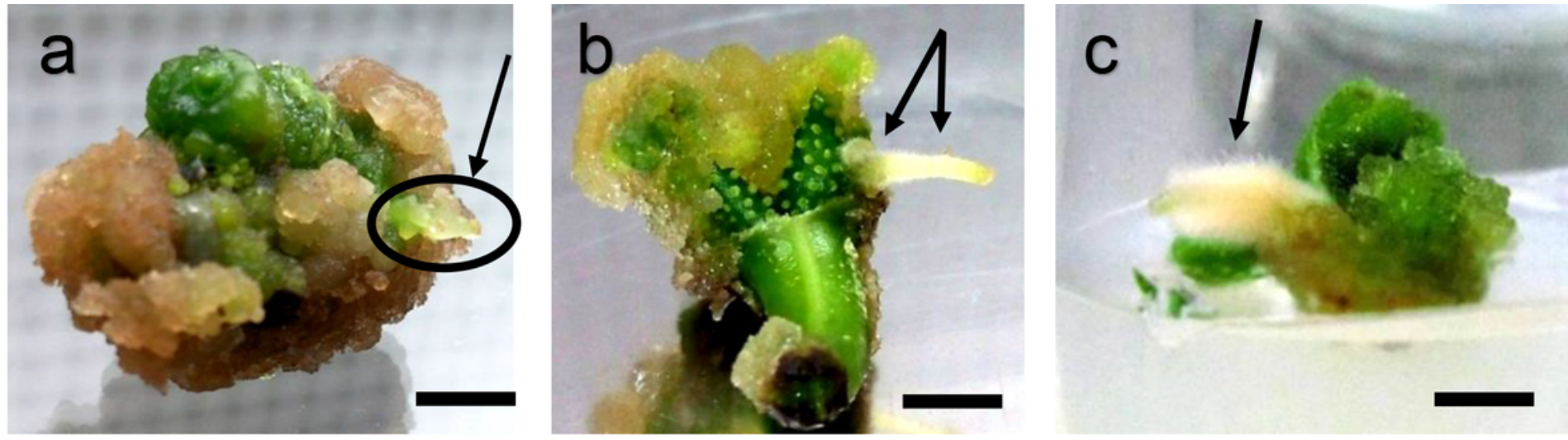

Figure 2

Adventitious rhizogenesis from ovary tissue within few weeks after culture initiation in the medium containing $27 \mu \mathrm{M}$ NAA. (a) a hair-free double root structure newly formed 4 weeks after culture initiation, (b) a slightly hairy double root structure 6 weeks after culture initiation , and (c) a single profusely hairy root 8 weeks after culture initiation. (Bar $=5 \mathrm{~mm}$ ). 

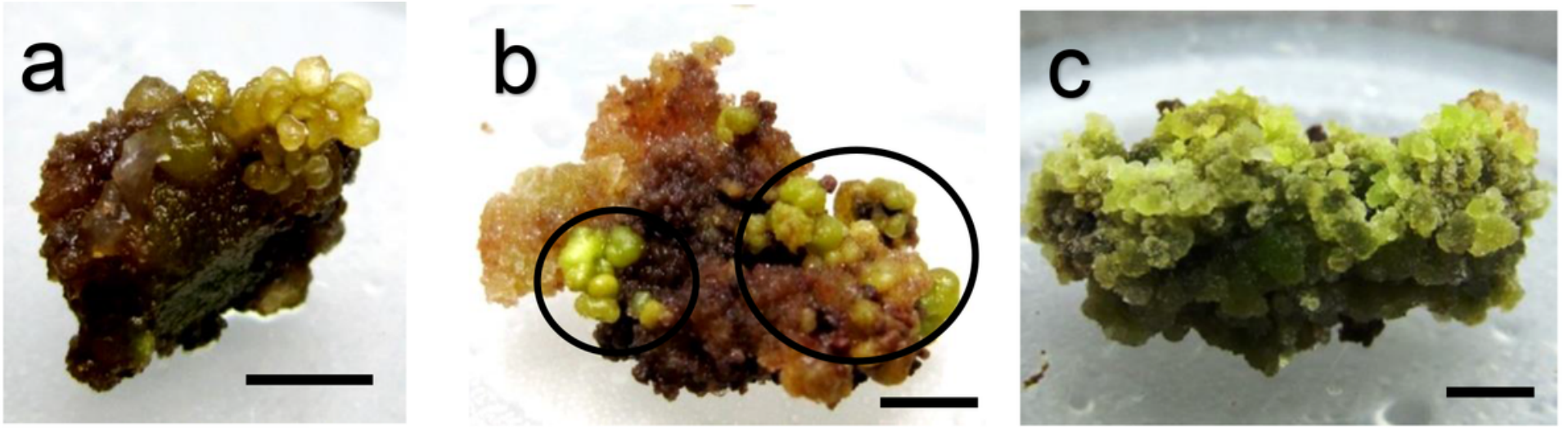

\section{Figure 3}

Various developmental stages of ovary-derived ECs from experiment 1 when transferred onto the proliferation media with or without auxins. (a) Formation of numerous pre-embryos, globular and heartshaped somatic embryos 8 weeks after transfer of EC onto the growth regulator-free medium (Control), (b) Formation of numerous well-developed globular and heart-shaped somatic embryos 8 weeks after transfer of EC onto the medium containing $54 \mu \mathrm{M}$ NAA and, (c) Proliferation and formation of compact, granular callus in MS modification No.1 medium containing a combination of $27 \mu \mathrm{M}$ NAA and $(12.3+14.3) \mu \mathrm{M}(\mathrm{IBA}+\mathrm{IAA})(\mathrm{Bar}=5 \mathrm{~mm})$.
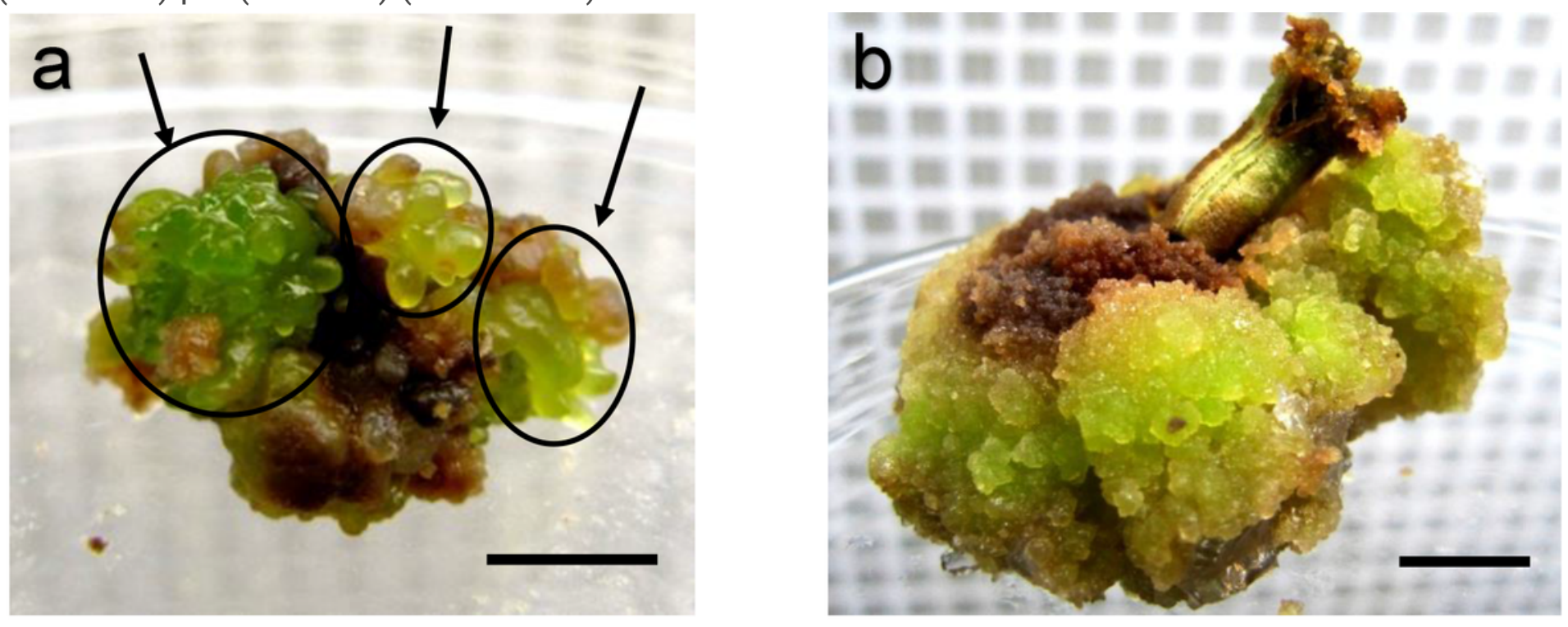

\section{Figure 4}

Different developmental patterns of ovary-derived EC and PEMs when transferred onto the MS modification No.2 medium supplemented with BA ten weeks after explant transfer; (a) Formation of numerous pre-embryos and secondary somatic embryos of various developmental stages (globular, heart-shaped, and torpedo) in the medium containing $0.9 \mu \mathrm{M} B A$, and (b) Profuse proliferation of compact granular EC in the medium containing $22.2 \mu \mathrm{M} \mathrm{BA}(B a r=5 \mathrm{~mm})$. 